DOI: $10.2478 / \mathrm{v} 10190-010-0003-5$

\title{
ROTIFERS AS INDICATORS OF CLIMATE CHANGE IN THE ANTARCTIC ENVIRONMENTS
}

\author{
AGNIESZKA POCIECHA \\ Institute of Nature Conservation, Polish Academy of Sciences \\ A. Mickiewicza 33, 31-120 Kraków, Poland \\ e-mail: pociecha@iop.krakow.pl
}

\begin{abstract}
An important question stated in the presented paper is: Could rotifers be the indicators of climate change in the Antarctic environments? Rotifers are one of the most important components of the invertebrate fauna of the Antarctic freshwater and terrestrial ecosystems. However, investigations of their distribution, diversity and an ecological role in the environment have been widely neglected, mainly due to the methodological and taxonomical difficulties. During the investigations 176 species of rotifers were found, including the endemic and cosmopolitan species. Their existence is directly proportional to microvariations of humidity factor. Scientists still have poor knowledge about the occurrence of rotifer species in recently studied habitats e.g. cryoconite holes, nunataks or soil. Probably rotifers could be the indicators of climate change in the Antarctic freshwater and terrestrial ecosystems but more investigations and monitoring studies are needed.
\end{abstract}

KEY WORDS: rotifers, biodiversity, freshwater ecosystem, terrestrial ecosystem, climatic impact, Antarctica.

\section{INTRODUCTION}

Antarctica is a continent with the most extreme environments. It is divided in three biogeographical zones: Maritime Antarctic, Sub-Antarctic and Continental Antarctic - last zone is divided into coastal and terrestrial part (Convey 2005). The SubAntarctic zone consists of isolated islands and archipelagos located at high latitudes in the Southern Ocean under its strong influence. The Maritime Antarctic is also a region under strong influence of the Southern Ocean but its impact is more seasonal in nature and limited to the short Antarctic summer period than in the Sub-Antarctic zone. The Continental Antarctic is the largest zone in terms of area (Fig. 1). 


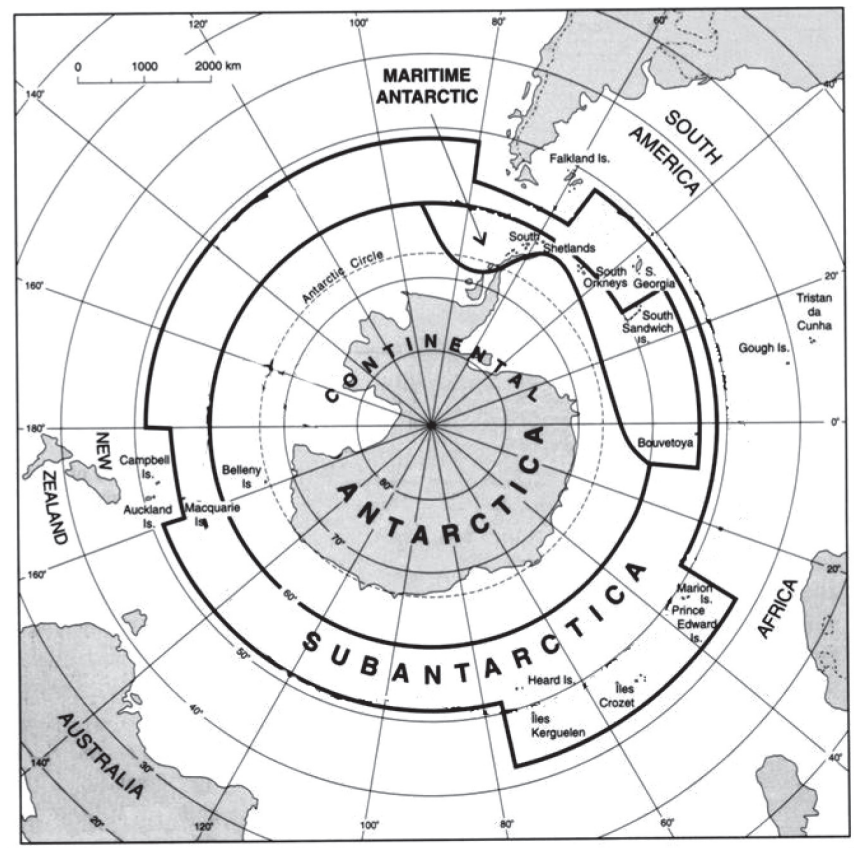

Figure 1. Map of the Antarctic three zones (after Ochyra 1998)

Biological and climatic characteristics of the Maritime Antarctic, Sub-Antarctic and Continental Antarctic zones show that they are unfamiliar for living organisms. Number of months with positive mean air temperature ranged from 4 to 6 in the Sub-Antarctic, 1 to 4 in the Maritime Antarctic, 0 to 1 in the costal part of the Continental Antarctic and is equal 0 in the inland part of the Continental Antarctic. In addition days with temperature above zero are not observed in the Continental Antarctic (Convey 2005).

The Antarctic terrestrial ecosystems are dominated by invertebrates and plants of cryptogamic groups (mosses, liverworts and lichens) (Convey 2005).

One of the most important components of freshwater and terrestrial Antarctic ecosystems are rotifers. They are organisms of microscopic size and can be well distributed by winds and dispersed by birds. It is very important factor in the last years because of the more frequent scientific expeditions and tourist visitors from year to year. The passive migration can be possible because the resting eggs of monogonont rotifers can endure very long dry and cold periods, whereas adult bdelloid species are able to preserve latent vitality frozen and encysted for some years in diapause (Paggi and Koste 1984).

Ricci and Fontaneto (2009) suggest a unifying framework, with dormancy representing the bdelloids' key feature. They hypothesise that dormancy, and especially the DNA repair mechanisms activated during dormancy recovery, might be responsible for all the unusual features present in the taxon. 
Rotifers can survive in harsh Antarctic environment having wide range of life history features including:

- ability to overwinter many times during development and lack of cue-mediated diapause,

- features of metabolism that allow relatively high growth rates (high reproduction) to be achieved in low temperatures,

- physiological adaptations giving high tolerance of low temperatures (correlated with tolerance of desiccation - anhydrobiosis).

In the eighties of 20 century rotifer investigations mainly concentrated on freshwater lakes and ponds and also on wet terrestrial areas overgrown by mosses (Priddle and Dartnall 1978, Dartnall 1983, Paggi and Koste 1984, Dartnall and Hollowday 1985). During the last 10 years researchers more intensively studied freshwater and terrestrial rotifers especially in ephemeral habitats e.g. cryoconite hole, nunataks or wallows (Adams et al. 2006, De Smet 2001, Dartnall 2005, Segers 2007, Sohlenius, Bostrom and Hirschfelder 1995).

Rotifers are well adapted to the Antarctic harsh environment, for this reason more interesting species can still be found and supply information about environmental climate changes.

The aim of presented paper was to show rotifers as an important component of the Antarctic freshwater and terrestrial ecosystems and as potential indicators of climate changes in the Antarctic environments.

\section{ROTIFER BIODIVERSITY}

The Antarctic terrestrial ecosystems are in general simplicity of structure. In these isolated habitats seasonal snow and ice cover affect the level of biodiversity. In the Maritime and Continental Antarctic temperatures are generally sufficiently low to cease biological activity during winter. Only at more southern locations habitats may become snow free and biological activity is possible. In most SubAntarctic islands the temperatures can remain positive or near to freezing point year-round and intermittent snow cover is observed, allowing continuous biological activity (Convey 1996, 2005). The level of biodiversity is also affected by soil properties as at many Antarctic locations and soils are poorly developed with low organic and nutrient content and vegetation is limited (Beyer and Bölter 2002, Lawley et al. 2004, Convey 2005).

Diversity refers to the range of variation of difference among some set of entities. Rotifer diversity thus refers to variation within their community. Biodiversity of rotifers is more or less governed by the interaction of abiotic and biotic processes. These small organisms with capability for high reproduction and anhydrobiosis are well adapted to harsh Antarctic habitat. 
Many authors have recognized that biodiversity and complexity of rotifer community decreased as environmental conditions in all three zones became more extreme (Convey 2005). Convey (2005) showed there are more than 59 rotifer species in Sub-Antarctic, more than 50 species in Maritime Antarctic and 13 species in Continental part. Different results were obtained basing on collected literature. The highest total number of rotifers (140 species) was found in Sub-Antarctic zone and the lowest in the Maritime Antarctic - 21 species (Tab. 1). Taking into consideration the number of rotifers in particular groups the highest number of Monogononta (122 species) was found in the Sub-Antarctic and of Bdelloida (32 species) in the Continental Antarctic (Tab. 1). At beginning of the eighties of 20 century more than 70 species of rotifers have been found in the terrestrial and freshwater ecosystems in the Antarctic and Sub-Antarctic regions (Dartnall 1983, 1993; Dartnall and Hollowday 1985, Paggi and Koste 1984). Current knowledge showed that 176 species of rotifers is known from Antarctic habitats: 138 species of Monogononta and 38 of Bdelloida.

Table 1. Number of rotifers species in the Antarctic biogeographical zones

\begin{tabular}{|l|c|c|c|}
\hline \multirow{2}{*}{ Rotifers species } & \multicolumn{3}{|c|}{ Antarctic zones } \\
\cline { 2 - 4 } & Sub-Antarctic & Maritime Antarctic & Continental Antarctic \\
\hline Monogononta & 122 & 19 & 29 \\
\hline Bdelloida & 18 & 2 & 32 \\
\hline Rotifera (total number) & 140 & 21 & 61 \\
\hline
\end{tabular}

\section{ROTIFERS IN TERRESTRIAL ECOSYSTEMS}

The terrestrial biota is poor. Cryptogams form the dominant vegetation, whilst animal communities consist almost entirely of invertebrates, the arthropods and microscopic groups being dominants (Smith 1984, Longton 1988, Convey 1997). The Antarctic terrestrial habitats are influenced by widely varying physical conditions both on short term (daily) and seasonal timescales. Temperature is one of the most important factor determining water and nutrient availability and the invertebrates activity. The effect of nutrient availability on the Antarctic ecosystems is only recently examined and few data exist (Convey 1997).

Rotifers, like most terrestrial invertebrates in Antarctica, are patchily distributed. The scientists have still very limited knowledge of the diversity of rotifers. Several studies have reported total numbers of rotifers (albeit not identified to species) across a range of habitats and environmental gradients. In the last ten years the scientists started studying rotifers more intensively in terrestrial ecosystems such as soil and mosses and also in ephemeral habitats like nunataks and cryoconite holes. Porazinska et al. (2004) reported two rotifer species (Philodina gregaria 
Murray and Cephalodella catellina Muller 1786) from cryoconite holes located on five glaciers in Victoria Land. However, despite the apparent similarities between cryoconite sediment and soil the biotic community consisted of species typical of lake and stream sediment (Porazinska et al. 2004) and the occurrence of these rotifer species in Antarctic soils remains uncertain (Adams et al. 2006). Soil moisture appears to be an important factor affecting rotifer abundance (Schwarz et al. 1993). To the contrary Sinclair and Sjursen (2001) found no relationship between rotifer abundance and soil moisture but a positive correlation between rotifer abundance and content of organic matter in soil.

In the beginning of nunatak studies only 16 species of bdelloids were found (Sohlenius et al. 1995) and 19 species after one year (Sohlenius et al. 1996) and few years later (Sholenius and Bostrom 2005).

Moss communities where rotifers were found are described in many papers as mosses falls and mosses squeezing (Dartnall 2005) or as aquatic moss e.g. occurring in deep water in the Moss Lake (Priddle and Dartnall 1978) or wet, green carpets of mosses (Paggi and Koste 1984). We still have little information about invertebrates from moss carpet.

On the basis of literature data presenting occurrence of rotifers in terrestrial habitats especially in soil, mosses, nunataks and cryoconite holes 61 species of rotifers was found. The highest number of rotifers was found in mosses: 47 species (28 from Monogononta and 19 from Bdelloida). In nunatak habitats only bdelloids were found (Fig. 2).

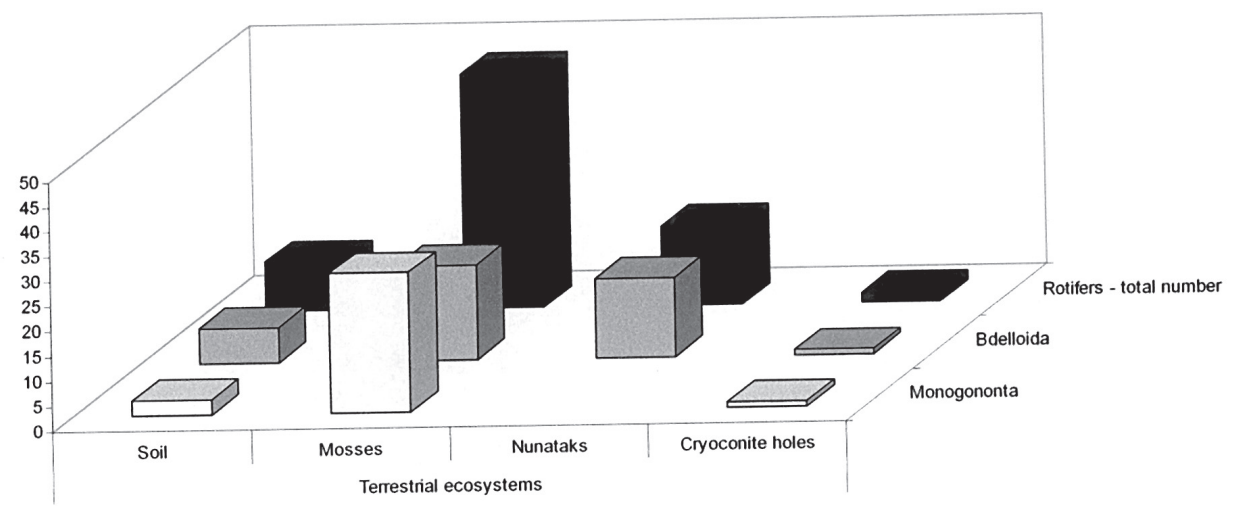

Figure 2. Number of rotifers species in terrestrial ecosystems

\section{ROTIFERS IN FRESHWATER ECOSYSTEMS}

Most of freshwater ecosystems of Antarctica are permanently unavailable because of the ice cover. However, even in the coldest Continental Antarctic liquid water may be present for short periods in such places as the surface of darker sub- 
strata, below glacier snouts and around melting snow patches. Freshwater habitats in the Maritime Antarctic are more available even during the winter time when thaws lead to the formation of a temporary water layer between the soil surface and snow layers, and in many parts of the Sub-Antarctic year-round (Convey 1997). However, water availability varies widely and often unpredictably on seasonal, geographical and micro-topographical scales in three zones of Antarctica. Water has been recognized as the most important factor affecting the distribution of Antarctic biota (Janetschek 1970, Kennedy 1993, Convey 1997).

The lakes and other water bodies show a wide variety of physical and chemical conditions. The limnological characteristics of the Antarctic lakes and smaller water bodies are strongly affected by their catchments, as well as by the occurrence of plants and animals, especially avifauna and mammals (Izaguirre et al. 1998, Vinocur and Unrein 2000). Coastal waters are usually polluted by seals and seabirds and influenced by sea water and sea breeze, whereas inland and upland lakes have mostly clearer water. Many Antarctic water bodies are covered by ice or frozen to bottom eight to nine months of the year (e.g. Paggi and Koste 1984, Pociecha 2008, Pociecha and Dumont 2008).

Rotifers occur in all types of freshwater habitats, and also in saline water and sea water. They have a wide tolerance on physicochemical water factors and great adaptive ability. Rotifers were found in many freshwater habitats from three Antarctic zones: coastal and inland lakes, ponds and pools, running waters (streams), hyporeic water, wallows (seal and penguins), seepages (algal and cyanobacteria mats), brackish and hipersaline waters. On the basis of literature data 158 species of rotifers were found in the Antarctic freshwater habitats. The highest number of rotifers was found in lakes (126 species) and ponds (124 species). In hipersaline habitats only bdelloids were found (Fig. 3).

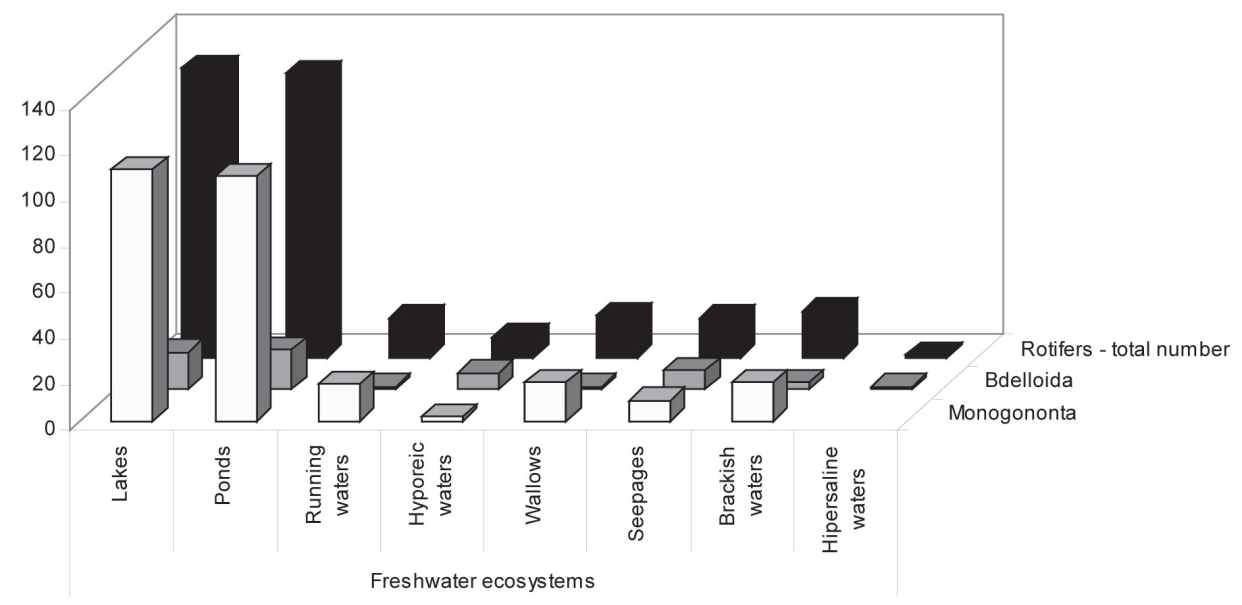

Figure 3. Number of rotifers species in freshwater ecosystems 


\section{„EXPANSION" OF ROTIFER (LECANE CLOSTEROCERCA SCHMARDA) ON THE COASTAL CONTINENTAL ANTARCTIC - IS IT A CONSEQUENCE A OF CLIMATE CHANGE?}

Lecane closterocerca is a cosmopolitan species with a wide $\mathrm{pH}$ and thermal tolerance. It appears in various biogeographical regions: nearctic, palearctic, pacific, neotropical, afrotropical, oriental, Australian and Antarctic (Segers 2007). L. clocterocerca was observed in plankton lakes and ponds, streams, wallows, brackish environment (freshwater habitat) and in soil (terrestrial habitat). It is a small rotifer, with dorsal plate $93 \mu \mathrm{m}$ long and $82 \mu \mathrm{m}$ wide and ventral plate $96 \mu \mathrm{m}$ (Dartnall and Hollowday 1985) (Fig. 4).

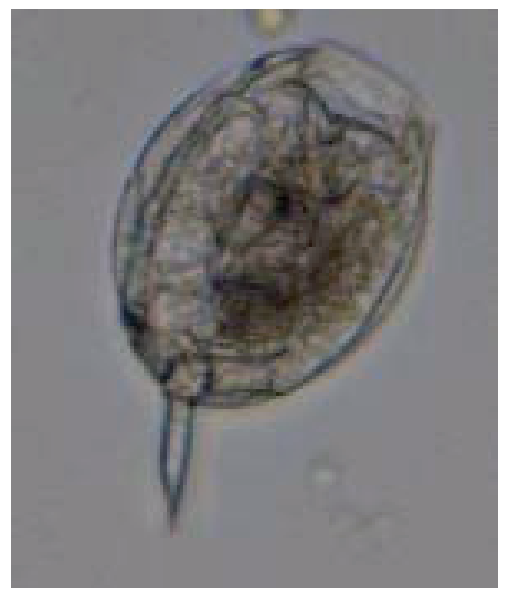

Figure 4. Monogonont rotifer Lecane clocterocerca Schmarda

This species was first time found in Antarctica in lakes in the milder northern part of South Georgia in the Sub-Antarctic region (Dartnall 1983, Dartnall and Hollowday 1985).

After 20 years Dartnall (2005) continued studies in freshwater ecosystems in South Georgia. He studied 21 lakes, 10 pools, 7 coastal pools, 3 streams, 2 seal and penguin wallows and 3 flooded moss carpets. L. closterocerca was found in lakes, pools, stream and wallows. De Smet (2001) found L. closterocerca in plankton lakes in Kerguelen Islands (Sub-Antarctic).

Until now L. closterocerca was found only in freshwater ecosystems of the Sub-Antarctic region. In recent time researchers have started investigations on rotifer occurrence in soil, nunataks and cryoconite holes. In $2009 \mathrm{~L}$. closterocerca was found in soil samples from Campo Icaro located near Antarctic Italian station "Terra Nova Bay" on the Victoria Land - Ross Sea Sector, Continental Antarctic (Pociecha unpubl. data and Fig. 5). 


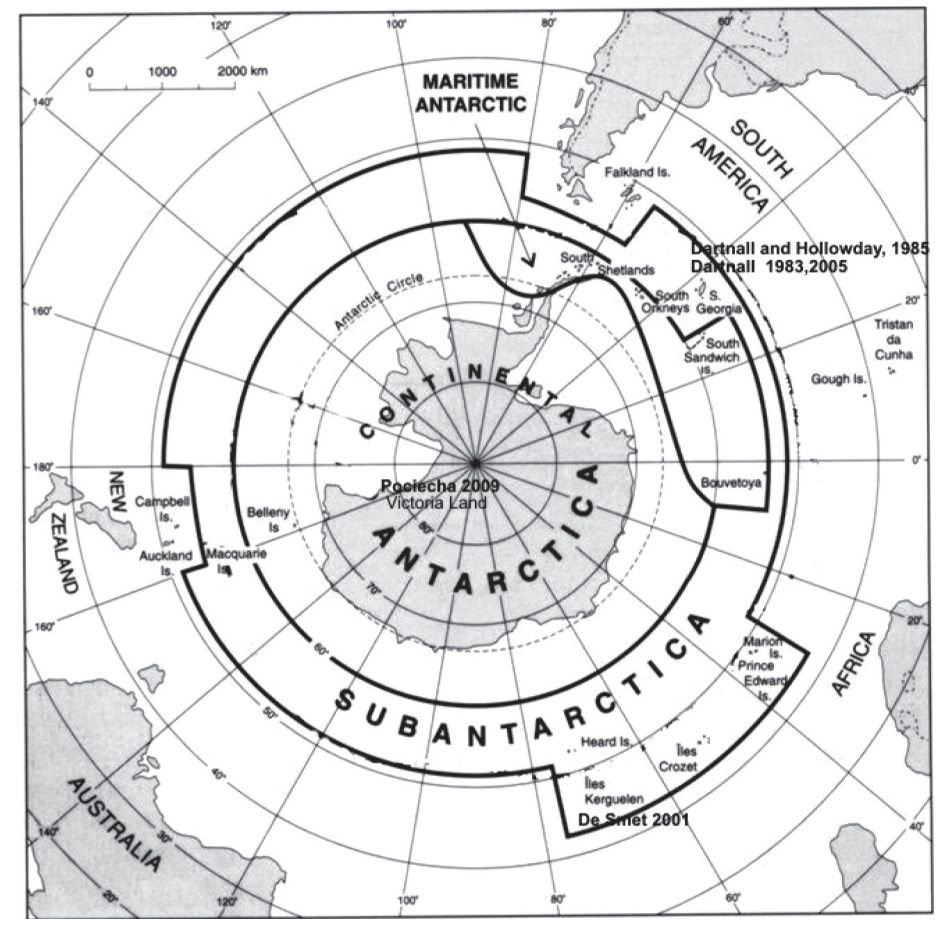

Figure 5. „Expansion” of rotifer L. clocterocerca

Now scientists put a question: is an "expansion" of L. closterocerca caused by climate changes or contribution of new scientists? The answer is probably not simple, it seems more complicated than it appears. But for L. closterocerca, being a cosmopolitan species well adapted to Antarctic habitats, its "expansion" could be a result of these two reasons.

\section{CONCLUSIONS}

Rotifers are organisms well adapted to harsh Antarctic environments and successfully colonize its various ecosystems, so for this reason could be good indicators of climate changes in Antarctica.

Invertebrates from Antarctic terrestrial habitats are particularly sensitive to human disturbance and climate change (Kennedy 1995, Virginia and Wall 1999). Although taking into account changes in the distribution of the Antarctic invertebrates they are often proposed as potential bioindicators of a changing climate (e.g. Kennedy 1994, 1995; Virginia and Wall 1999; Convey and Arnold 2000). There is only limited information on these communities, particularly at the most extreme latitudes, which are considered being particularly susceptible to change (Sinclair 2001). 
Present knowledge of distribution of rotifer species is still not sufficient, especially in the Antarctic environments. The future research subject could be a monitoring of rotifers in different Antarctic habitats with special concern in new species, invasive species, alien species and occurrence of recorded endemic rotifers.

\section{ACKNOWLEDGMENTS}

This study was co-financed by The Ministry of Science and Higher Education - grant titled: The role of environmental factors in forming biodiversity of soil rotifers in the Continental Antarctic (Victoria Land, Ross Sea Vector), no: NN 304 069033.

The author would like to thank M.Sc. M. Szul for linguistic correction.

\section{REFERENCES}

Adams B.J., Bardgett R.D., Ayres E., Wall D.H., Aislabie J., Bamforth S., Bargagli R., Cary C., Cavacini P., Connell L., Convey P., Fell J. W., Frati F., Hogg J.D., Newsham K. K., O’Donnell A., Russell N., Seppelt R. D. and Stevens M. J., 2006, Diversity and distribution of Victoria Land biota, Soil Biology and Biochemistry, 38, 3003-3018.

Beyer L. and Bölter M. (eds), 2002, Geoecology of Antarctic ice-free coastal landscapes, Ecological Studies Series, 154, Springer, Berlin, XXIV, 1-427.

Convey P., 1996, Overwintering strategies of terrestrial invertebrates in Antarctica - the significance of flexibility in extremely seasonal environments, Eur. J. Entomol., 93, 489-505.

Convey P., 1997, How are the life history strategies of Antarctic terrestrial invertebrates influenced by extreme environmental conditions? J. Therm. Biol., 22, 6, 429-440.

Convey P., 2005, Antarctic terrestrial ecosystems: responses to environmental change, Polarforschung, 75 (2-3), 101-111.

Convey P. and Arnold R.J., 2000, A potential invertebrate indicator of climate change on sub-Antarctic South Georgia, Cryo-Lett, 21, 69.

Dartnall H.J.G., 1983, Rotifers of the Antarctic and Subantarctic, Hydrobiologia, 104, $57-60$.

Dartnall, H.J.G., 1993, The rotifers of Macquarie Island, ANARE Res. Notes 89, 41 pp.

Dartnall H.J.G., 2005, Freshwater invertebrates of Subantarctic South Georgia, Journal of Natural History, 39, 3321-3342.

Dartnall H.J.G. and Hollowday E.D., 1985, Antarctic rotifers, Br. Antarct. Surv. Sci. Rep., 100, 146pp.

De Smet W. H., 2001, Freshwater Rotifera from plankton of the Kerguelen Islands (Subantarctica), Hydrobiologia, 446/447, 261-272.

Izaguirre I., Vinocur A., Mataloni G. and Pose M., 1998, Phytoplankton communities in relation to trophic status in lakes from Hope Bay (Antarctic Peninsula, Hydrobiologia, 369/370, 73-87. 
Janetschek H., 1970, Environments and ecology of terrestrial arthropods in the high Antarctic, [in:] Holdgate M. W. (ed.), Antarctic ecology, Academic Press, London, Vol. 2, 871-885.

Kennedy A. D., 1993, Water as a limiting factor in the Antarctic terrestrial environment: a biogeographical synthesis, Arct. Alp. Rrs., 25, 308-315.

Kennedy A.D., 1994, Simulated climate change: a field manipulation study of polar microarthropod community response to global warming, Ecography, 17, 131-140.

Kennedy A.D., 1995, Antarctic terrestrial ecosystem response to global environmental change, Ann. Rev. Ecol. Syst., 26, 683-704.

Lawley B., Ripley S., Bridge P. and Convey P., 2004, Molecular analysis of geographic patterns of eukaryotic diversity in Antarctic soils, Appl. Environm. Microbiol., 70, 5963-5972.

Longton R.E., 1988, Biology of polar bryophytes and lichens, Cambridge University Press, Cambridge.

Ochyra R., 1998, The moss flora of King George Island, Antarctica, Szafer Inst. of Botany, PAS, Cracow, XXIV, 279 pp.

Paggi S.J. and Koste W., 1984, Checklist of the rotifers recorded from Antarctic and Subantarctic areas, Senckenbergiana boil., 65, 169-178.

Pociecha A., 2008, Density dynamics of Notholca squamula salina Focke (Rotifera) in Lake Wujka, a freshwater Antarctic lake, Polar Biology, 31, 275-279.

Pociecha A. and Dumont H.J., 2008, Life cycle of Boeckella poppei Mrazek and Branchinecta gaini Daday (King George Island, South Shetlands), Polar Biology, 31, 245-248.

Porazinska D., Fountain A.G., Nylen T., Tranter M., Virginia R.A. and Wall D.H., 2004, The biodiversity and biogeochemistry of cryoconite holes from McMurdo dry valley glaciers, Antarctica, Arctic, Antarctic, and Alpine Research, 36, 84-91.

Priddle J. and Dartnall H.J.G., 1978, The biology of an Antarctic aquatic moss community, Freshwater Biology, 8, 469-480.

Ricci C. and Fontaneto D., 2009, The importance of being a bdelloid: Ecological and evolutionary consequences of dormancy, Italian Journal of Zoology, 76, 240-249.

Schwarz A.M.J., Green J.D., Green T.G.A., Seppelt R.D., 1993, Invertebrates associated with moss communities at Canada Glacier, southern Victoria Land, Antarctica, Polar Biology, 13, 157-162.

Segers H., 2007, Annotated checklist of the rotifers (Phylum Rotifera), with notes on nomenclature, taxonomy and distribution, Zootaxa, 1564, 104 pp.

Sinclair B.J., 2001, On the distribution of terrestrial invertebrates at Cape Bird, Ross Island, Antarctica, Polar Biol., 24, 394-400.

Sinclair B.J. and Sjursen H., 2001, Terrestrial invertebrate abundance across a habitat transect in Keble Valley, Ross Island, Antarctica, Pedobiologia, 45, 134-145.

Smith R. I. L., 1984, Terrestrial plant biology of the Antarctic and sub-Antarctic, [in:] Laws R. M. (ed.), Antarctic Ecology, Academic Press, London, 61-162.

Sohlenius B., Bostrom S. and Hirschfelder A., 1995, Nematodes, rotifers and tardigrades from nunataks in Dronning Maud Land, East Antarctica, Polar Biology, 15, 51-56.

Sohlenius B., Bostrom S. and Hirschfelder A., 1996, Distribution patterns of microfauna (nematodes, rotifers and tardigrades) on nunataks in Dronning Maud Land, East Antarctica, Polar Biology, 16, 191-200. 
Sohlenius B. and Bostrom S., 2005, The geographic distribution of metazoan microfauna on East Antarctic nunataks, Polar Biology, 28, 439-448.

Vinocur A. and Unrein F., 2000, Typology of lentic water bodies at Potter Peninsula (King George Island, Antarctica) based on physical-chemical characteristics and phytoplankton communities, Polar Biology, 23, 858-870.

Virginia R.A. and Wall D.H., 1999, How soils structure communities in the Antarctic Dry Valleys, BioScience, 49, 973-983. 